\title{
Efficiency of Blotter test and agar culture medium to detect Fusarium graminearum and Pyricularia grisea in wheat seeds ${ }^{1}$
}

\author{
Meyriele Pires de Camargo ${ }^{2 *}$, Maria Heloisa Duarte de Moraes ${ }^{2}$, \\ José Otávio Machado Menten ${ }^{2}$
}

\begin{abstract}
Seeds can be considered one of the most efficient forms to disseminate pathogens. Therefore, the use of healthy seeds is extremely important to establish a crop, and seed health testing must be performed to determine the seed sanitary quality. This study aimed to compare the efficiency of seed health testing to detect Pyricularia grisea and Fusarium graminearum in three samples of wheat seeds. Methods evaluated were Blotter test with freezing (BTF) and potato-dextrose-agar culture medium (PDA). The incubation temperatures were $20^{\circ} \mathrm{C}$ and $25^{\circ} \mathrm{C}$. From each sample, a subsample was submitted to seed asepsis using hypochlorite solution (1\%) and another analyzed without seed asepsis. The temperatures evaluated did not influence the detection of the pathogens. P. grisea incidence ranged from 4.5 to $17 \%$ with BTF without seed asepsis. The BTF with seed asepsis and PDA (with and without seed asepsis) presented pathogen incidence no higher than 1.5\%. Moreover, results suggested that most part of $P$. grisea inoculum was presented externally on seed tissues. PDA medium was more efficient to detect $F$. graminearum, independently of seed asepsis. By this method, pathogen incidence ranged from 3 to $39 \%$. F. graminearum incidence using BTF with seed asepsis varied from 0.5 to $1.5 \%$ and BTF without seed asepsis presented a pathogen incidence of 5.0 to $12.5 \%$. The Blotter test with freezing was more efficient to detect $P$. grisea while the PDA medium was more efficient to detect $F$. graminearum.
\end{abstract}

Index terms: Triticum aestivum, detection methods, seed pathology.

\section{Eficiência do método do papel de filtro e do meio de cultura agarizado na detecção de Fusarium graminearum e Pyricularia grisea em sementes de trigo}

\begin{abstract}
RESUMO - Sementes podem ser consideradas como uma das formas mais eficientes na disseminação de patógenos. Portanto, o uso de sementes sadias é de extrema importância para o estabelecimento de uma cultura e testes de sanidade devem ser realizados para determinar a sua qualidade sanitária. O presente trabalho teve como objetivo comparar a eficiência de métodos de sanidade na detecção de Pyricularia grisea e Fusarium graminearum em três amostras de sementes de trigo. Os métodos avaliados foram o papel de filtro com congelamento (PFC) e o meio de cultura batata-dextrose-ágar (BDA). As temperaturas de incubação foram $20^{\circ} \mathrm{C}$ e $25^{\circ} \mathrm{C}$. De cada amostra, uma submostra foi submetida a assepsia de sementes usando solução de hipoclorito (1\%) e outra analisada sem assepsia. As temperaturas analisadas não influenciaram na detecção dos patógenos. A incidência de $P$. grisea variou de 4,5 a 17\% no método PFC sem assepsia das sementes. O PFC com assepsia e o BDA (com e sem assepsia) apresentou incidência do patógeno inferior a 1,5\%. Além disso, os resultados sugeriram que a maior parte do inóculo de $P$. grisea estava presente externamente aos tecidos da semente. O meio BDA foi mais eficiente na detecção de $F$. graminearum, independentemente da assepsia das sementes. Por esse método, a incidência do patógeno variou de 3 a 39\%. A incidência de $F$. graminearum pelo PFC com assepsia variou de 0,5 a 1,5\% e o PFC sem assepsia apresentou incidência do patógeno de 5 a $12,5 \%$. O papel de filtro com congelamento foi mais eficiente na detecção de $P$. grisea enquanto o meio BDA foi mais eficiente na detecção de F. graminearum.
\end{abstract}

Termos para indexação: Triticum aestivum, métodos de detecção, patologia de sementes.

\footnotetext{
${ }^{1}$ Submitted on 11/01/2016. Accepted for publication on 09/11/2017.

${ }^{2}$ Departamento de Fitopatologia, USP/ESALQ, Caixa Postal 9, 13418-900 - Piracicaba, SP, Brasil.

*Corresponding author <meyrielecamargo@usp.br>
} 


\section{Introduction}

Wheat (Triticum aestivum L.) is one of the most important cereals for human consumption in the world, as well as in Brazil. Wheat production is concentrated in the southern region of Brazil, especially because the suitable climatic conditions for cultivation. The Brazilian production in 2016 was $6,726.8$ tons and the cultivated area was $2,118.4$ ha. The intern consumption of wheat in 2016 was estimated in $11,317.7$ tons. Therefore, Brazil is not self-sufficient in wheat production and the country imports about five to seven million tons of wheat every year (CONAB, 2017).

The occurrence of diseases is one of the causes to limit higher yields in wheat production. Gibberella zeae is the causal agent of Fusarium head blight (FHB), one of the most serious disease in wheat and other winter cereals. Fusarium graminearum is the predominant species of FHB (Wiese, 1991; Osborne and Stein, 2007; Reis and Casa, 2007, 2016). The disease reduces the quantity and the quality of the production. When the pathogen is associated with grains or seeds, mycotoxins can be produced, which are toxic for humans and animals (Neergaard, 1979; McMullen et al., 2012; Dweba et al., 2017). In addition, infected seeds are source of inoculum to Fusarium foot rot (Wiese, 1991; Reis and Casa, 2007, 2016). Wheat blast caused by Magnaporthe grisea (Pyricularia grisea) was first reported in Brazil in 1985 (Igarashi et al., 1986) and is another devastating wheat disease. The fungus infects mainly spikes and is common its occurrence in combination with Fusarium species. In addition to infection on spikes, leaf lesions may also occur under hot and humid conditions (Kohli et al., 2011; Saharan et al., 2016).

F. graminearum and P. grisea are necrotrophic pathogens and survives saprophytically on residues of corn, other host plant species and on seeds. P. grisea and Fusarium spp. are described colonizing all seed parts, including embryo, endosperm, perisperm, seed coat and pericarp (Agarwal and Sinclair, 1987). According to Bechtel et al. (1985) F. graminearum was most prevalent in aleurone and pericarp tissues. For $P$. grisea, the predominance of internal infection on seed tissues by dormant mycelium was suggested (Goulart and Paiva, 1993). Through seeds, microorganisms can be transported for long distances and easily introduced into new areas (Nasser, 1987). The incidence of F. graminearum on seeds was quantified in many studies (Telles Neto et al., 2007; Kabeere et al., 1997; Garcia Júnior et al., 2008; Kobayasti and Pires, 2011) and could be up to $48 \%$ (Kabeere et al., 1997; Danelli et al., 2012). For P. grisea, the pathogen incidence was also measured in different studies, and most of them reported incidences about 6 to 18\% (Goulart and Paiva, 1991;
Goulart and Paiva, 1993). However, pathogen incidences of $63 \%$ on seeds were also verified (Kobayasti and Pires, 2011). Management of FHB and wheat blast include the use of healthy seeds, crop rotation, anticipated sowing, and chemical control applied on over aerial parts or by seed treatment (Reis and Casa, 2007, 2016).

The use of healthy seeds are essential for preventing diseases and seed health testing must be performed to determine the sanitary quality of seeds. Besides the identification and quantification of pathogens, seed health tests provide information to determine the sanitary quality of storage seeds, and the requirement and efficiency of seed treatment (Lucca Filho, 1987). According to the Manual of Sanitary Seed Analysis (2009), methods usually recommended to detect pathogens on seeds were Blotter test and agar culture medium. The substrate used on Blotter test is filter paper moisten with sterile distilled water (Lucca Filho, 1987). Usually, this method is used for non-disinfested seeds and the technique of freezing is applied for monocotyledons crops to reduce seed germination process. Seeds were examined individually by the presence of typical structures of the pathogens using a stereoscopic microscope (Brasil, 2009). Some advantages of this technique are the detection of various fungi carried by seeds at the same time, easiness of installation and low cost (Lucca Filho, 1987; Neergaard, 1979; Machado et al., 2002; Mathur and Kongsdal, 2003; Brasil, 2009). Agar culture medium is routinely used as an alternate method for Blotter test. The agar medium is commonly used when the Blotter test does not offer suitable conditions for growth and for sporulation of fungi (Lucca Filho, 1987). Usually, seeds were disinfested with a hypochlorite solution to avoid the presence of saprophytic organisms. Pathogens are identified based on the characteristics of the colonies, such as shape, size and color (Brasil, 2009). Compared to the Blotter test, disadvantages of this method included a higher cost and a longer preparation time (Lucca Filho, 1987).

Blotter test with freezing and potato-dextrose-agar medium are methods recommended by the Manual of Sanitary Seed Analysis to detect pathogens in wheat seeds (Brasil, 2009) and are commonly used (Nasser, 1987; Goulart and Paiva, 1992; Reis and Casa, 1998; Celano et al., 2012; Reis et al., 1997; Luz, 2003; Casa et al., 2012). For both methods, the incubation temperature recommended by the Manual of Sanitary Seed Analysis is $20 \pm 2{ }^{\circ} \mathrm{C}$ (Brasil, 2009). However, the incubation temperature recommended by other reference books of seed pathology varies between 20 to $25^{\circ} \mathrm{C}$ (Lucca Filho, 1987; Neergaard, 1979; Machado et al., 2002; Mathur and Kongsdal, 2003). Therefore, routine analysis to detect seed-borne pathogens in wheat seeds commonly use different 
temperatures and detection methods, without an established pattern. The temperature influences germination, growth, reproduction, and other microorganism activities. Therefore, determining the most appropriate incubation temperature is essential to detect plant pathogens on seeds (Yorinori, 1987). Besides, information about the efficiency of seed health methods to detect different seed-borne pathogens are limited on literature. This kind of information is important to determine the sensibility of seed health methods and safely detect pathogens. This study aimed to evaluate the efficiency of Blotter test and agar culture medium to detect Fusarium graminearum and Pyricularia grisea in wheat seeds.

\section{Material and Methods}

Three seed samples of wheat identified as 1, 2 and 3 were collected in the growing season of 2009. Samples 1 and 2 were collected from Taquarituba-SP and sample 3 from Paranapanema-SP. To characterize samples, 400 seeds of each sample were analyzed using the Blotter test with freezing, according to recommendations of the Manual of Sanitary Seed Analysis (Brasil, 2009). The characterization of samples was conducted in October 2009 for samples 1 and 2, and in December 2009 for sample 3. The health test showed $27.0 \%, 46.2 \%$ and $44.0 \%$ of $P$. grisea for samples 1,2 and 3, respectively; $44.2 \%$, $21.5 \%$ and $21.8 \%$ of $F$. graminearum for samples 1,2 , and 3 , respectively; and for all samples analyzed less than $6.0 \%$ of $B$. sorokiniana and Bipolaris sp. was verified (Table 1). Samples were storage in refrigerator conditions. Comparison between seed health methods were conducted in April 2010. The methods used to evaluate the incidence of $F$. graminearum and $P$. grisea were Blotter test with freezing (BTF) and potato-dextrose-agar culture medium (PDA). The incubation temperatures tested were 20 and $25^{\circ} \mathrm{C}$ and seeds were evaluated with and without asepsis with hypochlorite solution (1\%).

The Blotter test with freezing was performed as described by Brasil (2009). For treatments with asepsis, seeds were immersed in sodium hypochlorite solution (1\%) for $3 \mathrm{~min}$. Wheat seeds were placed into acrylic plates $(25$ seeds per plate) and incubated in incubation chamber under $20^{\circ} \mathrm{C}$ with alternating $12 \mathrm{~h}$ period of darkness and fluorescent white light, where they remained for $24 \mathrm{~h}$. Thereafter, seeds were transferred to $-20^{\circ} \mathrm{C}$ for $24 \mathrm{~h}$, and after freezing, they were incubated for 5 days at $20{ }^{\circ} \mathrm{C}$ and $25{ }^{\circ} \mathrm{C}$, according to the temperature evaluated and at the same conditions previously described. For PDA, a potato broth $(20 \%$ of potato, $2 \%$ of dextrose, and $1.5 \%$ of agar) was autoclaved and added into acrylic plates. For treatments with seed asepsis, wheat seeds were immersed in sodium hypochlorite solution $(1 \%)$ for 3 $\min$. Ten wheat seeds were added into each plate and incubated in incubation chamber for 7 days with alternating $12 \mathrm{~h}$ period of darkness and fluorescent light at $20^{\circ} \mathrm{C}$ and $25^{\circ} \mathrm{C}$ according to the temperature evaluated.

Treatments were evaluated on the $7^{\text {th }}$ day after the test installation, for both methods. Initial seed examination was performed based on the characteristics of colonies for each fungus for PDA method. To evaluate the BTF method, seeds were examined with stereoscopic microscope (Brasil, 2009). The pathogens identification was based on their morphological characteristics (Barnett and Hunter 1998; Alexopoulos et al. 1996; Brasil, 2009). In case of doubts, slides were prepared to be observed in an optical microscope for both methods.

The experimental design was completely randomized with four replications of 50 seeds. Mean values were compared by Tukey test at $5 \%$ of significance, using the program Sisvar (Ferreira, 2011). The data were processed using square root of $x+0.5$.

\section{Results and Discussion}

Comparing the seed analysis performed to characterize the sanitary quality of seed samples (Table 1) and the analysis performed to evaluate the health seed methods (Table 2, Table 3) it was verified reduction on incidence of $P$. grisea and $F$. graminearum over the storage period. The seed storage period could interfere on the percentage of seed infection and pathogen incidence tends to decrease with longer storage periods. Survival of seed-borne pathogens also depends on the amount of inoculum, location of inoculum, and type of survival propagule (Agarwal and Sinclair, 1987). P. grisea and F. graminearum invade seeds before harvest, when the crop is still in the field, and because of this they are classified as field fungi. Conditions of temperature and humidity interferes on the survival of field fungi during the storage period (Wetzel, 1987). In addition to Pyricularia grisea and Fusarium graminearum, Aspergillus sp., Penicillium sp., Bipolaris sorokiniana, Bipolaris sp. and Alternaria alternata

Table 1. Initial characterization of fungi incidence (\%) on three samples of wheat seeds using the Blotter test with freezing without seed asepsis and incubation temperature of $20^{\circ} \mathrm{C}$.

\begin{tabular}{lccc}
\hline \multicolumn{1}{c}{ Fungus } & Sample 1 & Sample 2 & Sample 3 \\
\hline Pyricularia grisea & 27.0 & 46.2 & 44.0 \\
Fusarium graminearum & 44.2 & 21.5 & 21.8 \\
Bipolaris sorokiniana & 6.0 & 0.5 & 1.8 \\
Bipolaris sp. & 2.0 & 2.0 & 0.0 \\
\hline
\end{tabular}


Table 2. Incidence (\%) of Pyricularia grisea in three samples of wheat seeds using the Blotter test with freezing (BTF) and the potato-dextrose-agar medium (PDA), with seed asepsis (A) and without seed asepsis (WA), incubated at $20^{\circ} \mathrm{C}$ and $25^{\circ} \mathrm{C}$.

\begin{tabular}{lccc}
\hline \multicolumn{1}{c}{ Treatments } & Sample 1 & Sample 2 & Sample 3 \\
\hline BTF A $20^{\circ} \mathrm{C}$ & $0.50 \mathrm{a}^{*}$ & $1.00 \mathrm{ab}$ & $1.50 \mathrm{a}$ \\
BTF A $25{ }^{\circ} \mathrm{C}$ & $0.50 \mathrm{a}$ & $0.50 \mathrm{ab}$ & $0.50 \mathrm{a}$ \\
BTF WA $20{ }^{\circ} \mathrm{C}$ & $8.00 \mathrm{c}$ & $4.50 \mathrm{bc}$ & $17.00 \mathrm{~b}$ \\
BTF WA $25{ }^{\circ} \mathrm{C}$ & $4.50 \mathrm{bc}$ & $5.00 \mathrm{c}$ & $11.50 \mathrm{~b}$ \\
PDA A $20^{\circ} \mathrm{C}$ & $0.00 \mathrm{a}$ & $0.50 \mathrm{ab}$ & $0.00 \mathrm{a}$ \\
PDA A $25^{\circ} \mathrm{C}$ & $0.50 \mathrm{a}$ & $0.00 \mathrm{a}$ & $0.50 \mathrm{a}$ \\
PDA WA $20^{\circ} \mathrm{C}$ & $1.50 \mathrm{ab}$ & $0.50 \mathrm{ab}$ & $1.00 \mathrm{a}$ \\
PDA WA $25^{\circ} \mathrm{C}$ & $1.00 \mathrm{ab}$ & $0.00 \mathrm{a}$ & $0.00 \mathrm{a}$ \\
\hline \multicolumn{1}{c}{$\mathrm{CV}(\%)$} & 38.99 & 44.97 & 33.65 \\
\hline
\end{tabular}

*Means followed by the same letter in the column do not differ by Tukey test $(\mathrm{p}<0.05)$.

were also detected on seed samples. Because these fungi were observed at low incidence (less than $0.3 \%$ ) and since they were not the focus of this study, they were excluded from the analysis.

No differences were verified to $P$. grisea and $F$. graminearum incidence between the temperatures of $20^{\circ} \mathrm{C}$ and $25^{\circ} \mathrm{C}$, for both methods (Table 2 and Table 3). Gashaw et al. (2014) verified higher values of mycelial growth of $P$. grisea at $30^{\circ} \mathrm{C}$, but no statistic difference was verified at the temperatures of 20 ${ }^{\circ} \mathrm{C}$ and $25^{\circ} \mathrm{C}$. Hajano et al. (2013) observed significative lower values of colony growth and sporulation of $P$. grisea at $20{ }^{\circ} \mathrm{C}$ compared to $25^{\circ} \mathrm{C}$. Higher mycelial growth of $F$. graminearum was observed at $25^{\circ} \mathrm{C}$ in some studies (Hudec and Muchová, 2010; Neagu and Borda, 2013). Otherwise, a higher mycelial growth of $F$. graminearum was verified at $20{ }^{\circ} \mathrm{C}$ compared to $25^{\circ} \mathrm{C}$ by Garcia et al. (2012). According to our results, the temperatures of $20^{\circ} \mathrm{C}$ and $25^{\circ} \mathrm{C}$ provided no differences in the pathogen incidence and can be both used to detect P. grisea and $F$. graminearum in wheat seeds.

A higher incidence of P. grisea (4.5 to $17.0 \%$ ) was detected through the BTF method, without seed asepsis, at both temperatures. On the other hand, the BTF with seed asepsis presented lower levels of pathogen incidence ( 0.5 to $1.0 \%$ ), indicating that the highest percentage of inoculum was presented on the outer surface of seeds and not within seed tissues (Table 2). PDA method provided low levels of $P$. grisea incidence ( 0.0 to $1.5 \%)$. Since slow-growing fungi are easily hidden by others (Yorinori, 1987), it is suggested that P. grisea has a slower development compared to other fungi, such as $F$. graminearum, and may be hampered by a faster development of them.

The PDA culture medium was the most efficient method to
Table 3. Incidence (\%) of Fusarium graminearum in three samples of wheat seeds using the Blotter test with freezing (BTF) and the potato-dextrose-agar medium (PDA), with seed asepsis (A) and without seed asepsis (WA), incubated at $20^{\circ} \mathrm{C}$ and $25^{\circ} \mathrm{C}$.

\begin{tabular}{lrcc}
\hline \multicolumn{1}{c}{ Treatments } & Sample 1 & Sample 2 & Sample 3 \\
\hline BTF A $20{ }^{\circ} \mathrm{C}$ & $0.50 \mathrm{a}^{*}$ & $1.50 \mathrm{a}$ & $0.50 \mathrm{a}$ \\
BTF A $25{ }^{\circ} \mathrm{C}$ & $0.50 \mathrm{a}$ & $1.00 \mathrm{a}$ & $1.00 \mathrm{ab}$ \\
BTF WA $20{ }^{\circ} \mathrm{C}$ & $12.50 \mathrm{~b}$ & $8.50 \mathrm{bc}$ & $5.00 \mathrm{bc}$ \\
BTF WA $25{ }^{\circ} \mathrm{C}$ & $6.50 \mathrm{~b}$ & $5.00 \mathrm{ab}$ & $6.00 \mathrm{c}$ \\
PDA A $20{ }^{\circ} \mathrm{C}$ & $35.00 \mathrm{c}$ & $14.00 \mathrm{bcd}$ & $4.00 \mathrm{abc}$ \\
PDA A $25{ }^{\circ} \mathrm{C}$ & $37.00 \mathrm{c}$ & $16.00 \mathrm{~cd}$ & $7.50 \mathrm{c}$ \\
PDA WA $20^{\circ} \mathrm{C}$ & $39.00 \mathrm{c}$ & $22.50 \mathrm{~d}$ & $3.00 \mathrm{abc}$ \\
PDA WA $25^{\circ} \mathrm{C}$ & $32.50 \mathrm{c}$ & $17.00 \mathrm{~cd}$ & $7.50 \mathrm{c}$ \\
\hline \multicolumn{1}{c}{$\mathrm{CV}(\%)$} & 14.28 & 22.08 & 27.32 \\
\hline
\end{tabular}

*Means followed by the same letter in the column do not differ by Tukey test $(\mathrm{p}<0.05)$.

detect $F$. graminearum, independently of temperature and seed asepsis (Table 3). For PDA, pathogen incidence ranged from 32.5 to $39.0 \%$ in sample $1,14.0$ to $22.5 \%$ in sample 2 , and 3.0 to $7.5 \%$ in sample 3 . However, the use of PDA without asepsis is not recommended, since many contaminating fungi may develop (Lucca Filho, 1987). The pathogen incidence using the BTF and seed asepsis varied from 0.5 to $1.5 \%$ while the BTF without seed asepsis presented a pathogen incidence of 5.0 to $12.5 \%$. Therefore, BTF presented a lower sensibility to detect $F$. graminearum compared to PDA medium. These results differed from that obtained by Garcia Júnior et al. (2008), in which no significant differences were observed on $F$. graminearum incidence between semi-selective mediums and BTF.

The results obtained in the study showed that is not always possible to safely detect all fungi in wheat seeds by the same method. Celano et al. (2012) compared Blotter test with freezing and Blotter test with water restriction and verified the first one was more efficient to detect Drechslera triticirepentis, Fusarium graminearum and Alternaria alternata while Pyricularia grisea was detected at a higher incidence in Blotter test with water restriction. To detect Bipolaris sorokiniana in wheat and barley seeds, Barba et al. (2002) observed greater efficiency of the Blotter test with freezing and Reis' selective medium in comparison to other seed health testing. On routine laboratories, it is desirable that the same seed health method be capable to detect most part of pathogens transported by seeds. Information about the occurrence of diseases in the production field where seeds were produced are essential to choose the most appropriate seed health testing. When wheat blast and Fusarium head blight occur simultaneously it is recommended to use Blotter 
test with freezing and PDA culture medium to detect $P$. grisea and $F$. graminearum. Other methods more sophisticated could also be used to detect both pathogens. Molecular techniques, such as PCR may potentially facilitate the detection of seedborne pathogens. It is important to conduct comparative tests between different detection methods to define the method with greater sensibility and specificity to pathogens transmitted by seeds. Moreover, limited information about the efficiency of detection tests are available in the literature.

\section{Conclusions}

The results showed significant difference in the sensibility of seed healthy methods to detected Pyricularia grisea and Fusarium graminearum in wheat seeds. While the Blotter test with freezing without seed asepsis was more efficient to detect $P$. grisea, the PDA medium was more efficient to detect F. graminearum.

\section{References}

AGARWAL, V.K; SINCLAIR, J.B. Principles of seed pathology. v.1 Boca Raton: CRC Press, 1987. 176p.

ALEXOPOULOS, C.J.; MIMS, C. W.; BLACKWELL, M. Introductory mycology. 4.ed. New York: John Wiley \& Sons, 1996. 870p.

BARBA, J.T.; REIS, E.M.; FORCELINI, A.C. Comparação de métodos para detecção de Bipolaris sorokiniana em sementes de cevada. Fitopatologia Brasileira, v.27, n.4, p.389-394, 2002. http://www.scielo.br/scielo.php?script=sci_ arttext\&pid=S0100-41582002000400009

BARNETT, H. L.; HUNTER, B. B. Illustrated genera of imperfect fungi. 4.ed. St.Paul: The American Phytopathological Society, 1998. 218p.

BECHTEL, D.B.; KALEIKAU, L.A.; GAINES, R.L.; SEITZ, L.M. The effects of Fusarium graminearum infection on wheat kernels. Cereal Chemists, v.62, n.3, p.191-197, 1985.

BRASIL. Ministério da Agricultura, Pecuária e Abastecimento. Manual de Análise Sanitária de Sementes. Ministério da Agricultura, Pecuária e Abastecimento. Secretaria de Defesa Agropecuária. Brasília: MAPA/ ACS, 2009. 200p. http://www.agricultura.gov.br/assuntos/insumosagropecuarios/insumos-agricolas/sementes-e-mudas/publicacoessementes-e-mudas/manual-de-analise-sanitaria-de-sementes

CASA, R.T.; KUHNEM JUNIOR, P.R.; BOGO, A.; BELANI, A.M.B.; BOLZAN, J.M.; OLIVEIRA, F.S.; BLUM, M.M.C. Survey, survival and control of Alternaria alternata in wheat seeds. Revista Brasileira de Sementes, v.34, n.3, p.358-365, 2012. http://www.scielo. br/scielo.php?script=sci_arttext\&pid=S0101-31222012000300001
CELANO, M.M.; MACHADO, J.C.; JACCOUD-FILHO, D.S; GUIMARÃES, R.M. Avaliação do potencial de uso da restrição hídrica em teste de sanidade de sementes de trigo visando à detecção de fungos. Revista Brasileira de Sementes, v.34, n.4, p.613-618, 2012. http://www.scielo.br/scielo.php?script=sci_ arttext\&pid=S0101-31222012000400012

CONAB. Companhia Nacional de Abastecimento. Acompanhamento da safra brasileira de grãos. Brasília: 2017. http://www.conab.gov.br/ OlalaCMS/uploads/arquivos/17_06_08_09_02_48_boletim_graos_ junho_2017.pdf. Accessed on: Jun $20^{\text {th }}, 2017$.

DANELLI, A.D.; VIANA, E.; FIALLOS, F.G. Fungos patogênicos detectados em sementes de trigo de ciclo precoce e médio, produzidos em três lugares do Rio Grande do sul, Brasil. Sciencia Agropecuaria, v.1, p.67-74, 2012. http://www.redalyc.org/pdf/3576/357633701009.pdf

DWEBA, C.C.; FIGLAN, S.; SHIMELIS, H.A.; MOTAUNG, T.E.; SYDENHAM, S.; MWADZINGENI, L.; TSILO, T.J. Fusarium head blight of wheat: pathogenesis and control strategies. Crop Protection, v.91, p.114-122, 2017. http://www.sciencedirect.com/ science/article/pii/S0261219416302794

FERREIRA, D.F. Sisvar: a computer statistical analysis system. Ciência e Agrotecnologia, v.35, n.6, p.1039-1042, 2011. http://www. scielo.br/scielo.php?pid=S1413-70542011000600001\&script=sci_ arttext\&tlng $=\mathrm{pt}$

GARCIA, D.; BARROS, G.; CHULZE, S.; RAMOS, A.J.; SANCHIS, V.; MARÍN, S. Impact of cycling temperatures on Fusarium verticillioides and Fusarium graminearum growth and mycotoxins production in soybean. Journal of the Science of Food and Agriculture, v.92, p.2952-2959, 2012. http://onlinelibrary.wiley. com/doi/10.1002/jsfa.5707/epdf

GARCIA JÚNIOR, D.; VECHIATO, M.H.; MENTEN, J.O.M. Comparação de métodos para a detecção de Fusarium graminearum em sementes de trigo (Triticum aestivum L.). Summa Phytopathologica, v.34, n.2, p.164-167, 2008. http://www.scielo.br/ scielo.php?script=sci_arttext\&pid=S0100-54052008000200010

GASHAW, G.; ALEMU, T.; TESFAYE, K. Morphological, physiology and biochemical studies on Pyricularia grisea isolates causing Blast disease on finger millet in Ethiopia. Journal of Applied Biosciences, v.74, p.6059-6071, 2014. http://www.ajol.info/index. $\mathrm{php} / \mathrm{jab} / \mathrm{article} / \mathrm{view} / 101790$

GOULART, A.C.P; PAIVA, F.A. Controle de Pyricularia oryzae e Helminthosporium sativum pelo tratamento de sementes de trigo com fungicidas. Pesquisa Agropecuária Brasileira, v.26, n.11/12, p.1983-1988, 1991.

GOULART, A.C.P.; PAIVA, F.A. Fungos associados às sementes de trigo (Triticum aestivum L.) produzidas no Mato Grosso do Sul em 1990 e 1991. Revista Brasileira de Sementes, v.14, n.2, p.221-225, 1992.

GOULART, A.C.P.; PAIVA, F.A. Sobrevivência de Pyricularia oryzae cav. em sementes de trigo (Triticum aestivum L.) armazenadas em diferentes ambientes. Revista Brasileira de Sementes, v. 15, n.2, p.153-156, 1993. 
HAJANO, J.U.D; LODHI, A.M.; KHANZADA, M.A.; RAJPUT, M.A.; SHAH, G.S. Influence of abiotic factors on the vegetative growth and sporulation of Magnaporthe oryzae couch. Pakistan Journal of Phytopathology, v.25, p.65-70, 2013. http://pjp.pakps. com/index.php/PJP/article/view/12

HUDEC, K.; MUCHOVÁ, D. Influence of temperature and species origin on Fusarium spp. and Microdochium nivale pathogenicity to wheat seedlings. Plant Protection Science, v.46, n.2, p.59-65, 2010. http://agriculturejournals.cz/publicFiles/21180.pdf

IGARASHI, S.; UTIAMADA, C.M.; IGARASHI, L.C.; KAZUMA, A.H.; LOPES, R.S. Pyricularia em trigo. 1. Ocorrência de Pyricularia sp. no estado do Paraná. Fitopatologia Brasileira, v.11, n.2. p.351-352, 1986.

KABEERE, F.; HILL, M.J.; HAMPTON, J.G. Effect of maize seed storage conditions on the survival of Fusarium spp. Seed Science and Technology, v.25, n.2, p.329-332, 1997.

KOBAYASTI, L.; PIRES, A.P. Levantamento de fungos em sementes de trigo. Pesquisa Agropecuária Tropical, v.41, n.4, p.572578, 2011. http://www.scielo.br/pdf/pat/v41n4/a16v41n4.pdf

KOHLI, M.M.; MEHTA, Y.R.; GUZMAN, E.; VIEDMA, L.; CUBILLA, L.E. Pyricularia blast - a threat to wheat cultivation. Czech Journal of Genetics and Plant Breeding, v.47, p.130-134, 2011. http://www.agriculturejournals.cz/publicFiles/48968.pdf

LUCCA FILHO, A.O. Metodologia dos testes de sanidade de sementes. In: SOAVE, J.; WETZEL, M.M.V.S. (Ed.). Patologia de Sementes. Campinas: Fundação Cargill, 1987, p.430-440.

LUZ, W.C. Avaliação dos tratamentos biológico e químico na redução de patógenos em semente de trigo. Fitopatologia Brasileira, v.28, n.1, p.093-095, 2003. http://www.scielo.br/scielo.php?script=sci arttext\&pid=S0100-41582003000100014

MACHADO, J.C.; LANGERAK, C.J.; JACCOUD-FILHO, D.S. Seed-borne fungi: a contribution to routine seed health analysis. Lavras: International Seed Testing Association, 2002. 138p.

MATHUR, S.B.; KONGSDAL, O. Common laboratory seed health testing methods for detecting fungi. Bassersdorf: International Seed Testing Association, 2003. 425p.

MCMULLEN, M.; BERGSTROM, G.; WOLF, E.; DILL-MACKY, R.; HERSHMAN, D.; SHANER, G.; VAN SANFORD, D. A unified effort to fight and enemy of wheat and barley: Fusarium head blight. Plant Disease, v.96, n.12, p.1712-1728, 2012. http://apsjournals. apsnet.org/doi/pdf/10.1094/PDIS-03-12-0291-FE

NASSER, L.C.B. Testes de sanidade em sementes de trigo (Triticum aestivum L.). In: SOAVE, J.; WETZEL, M.M.V.S. (Ed.). Patologia de Sementes. Campinas: Fundação Cargill, 1987, p.469-480.
NEAGU, C.; BORDA, D. Modelling the growth of Fusarium graminearum on barley and wheat media extract. Romanian Biotechnological Letters, v.18, n.4, p.8489-8498, 2013. http://www. rombio.eu/vol18nr4/13\%20Daniela\%20Borda.pdf

NEERGAARD, P. Seed Pathology. London: Mac Millan Press, 1979. 1219p.

OSBORNE, L.E.; STEIN, J.M. Epidemiology of Fusarium head blight on small-grain cereals. International Journal of Food Microbiology, v.119, p.103-108, 2007. http://www.sciencedirect. com/science/article/pii/S0168160507003947

REIS, E.M.; CASA, R.T. Patologia de sementes de cereais de inverno. Passo Fundo: Aldeia Norte Editora, 1998. 88p.

REIS, E.M.; CASA, R.T. Doenças dos cereais de inverno: diagnose, epidemiologia e controle. Lages: Graphel, 2007. 176p.

REIS, E.M.; CASA, R.T. Doenças do trigo. In: AMORIM, L.; REZENDE, J.A.M.; BERGAMIN FILHO, A.; CAMARGO, L.E.A. (Ed.). Manual de Fitopatologia, v. 2: doenças das plantas cultivadas. 5 ed. Ouro Fino: Agronômica Ceres, 2016. p.737-744.

REIS, E.M.; CASA, R.T.; BLUM, M.M.C.; SANTOS, H.P.; MEDEIROS, C.A. Efeito de práticas culturais na severidade de manchas foliares do trigo e sua relação com a incidência de fungos patogênicos na semente colhida. Fitopatologia Brasileira, v.22, n.3, p.407-412, 1997.

SAHARAN, M.S.; BHARDWAJ, S.C.; CHATRATH, R.; SHARMA, P.; CHOUDHARY, A.K.; GUPTA, R.K. Wheat blast disease - an overview. Journal of Wheat Research, v.8, n.1, p.1-5, 2016. http:// epubs.icar.org.in/ejournal/index.php/JWR/article/view/60113/24724

TELLES NETO, F.X.B.; REIS, E.M.; CASA, R.T. Viabilidade de Fusarium graminearum em sementes de trigo durante o armazenamento. Summa Phytopathologica, v.33, n.4, p.414-415, 2007. http://www.scielo. br/scielo.php?script=sci_arttext\&pid=S0100-54052007000400017\&lng $=$ en\&nrm=iso

WETZEL, M.M.V.S. Fungos de armazenamento. In: SOAVE, J.; WETZEL, M.M.V.S. (Ed.). Patologia de Sementes. Campinas: Fundação Cargill, 1987, p.260-275.

WIESE, M.V. Compendium of wheat diseases. 2 ed. St. Paul: APS Press, 1991. 112p.

YORINORI, J.T. Fatores que afetam os resultados dos testes de sanidade envolvendo incubação. In: SOAVE, J.; WETZEL, M.M.V.S. (Ed.). Patologia de Sementes. Campinas: Fundação Cargill, 1987, p.299-312. 